\title{
UJI DAYA HAMBAT FILTRAT DAUN CIPLUKAN (Physalis angulata linn) TERHADAP PERTUMBUHAN BAKTERI Staphylococcusaureus
}

\author{
Siti Risma Rahayu ${ }^{1}$, Maruni Wiwin Diarti ${ }^{2}$ \\ ${ }^{1-2}$ Jurusan Analis Kesehatan, Poltekkes Kemenkes Mataram, Indonesia
}

\begin{tabular}{l}
\hline \hline Article Info \\
\hline Article history: \\
Received Jun $15^{\text {th }}, 2018$ \\
Revised Aug $25^{\text {th }}, 2018$ \\
Accepted Sept $7^{\text {th }}, 2018$ \\
\hline
\end{tabular}

Keyword:

Staphylococcus aureus,

Ciplukan,

Diameter zone,

\begin{abstract}
Staphylococcus aureus bacteria are cocus-shaped bacteria and are gram-positive, this bacteria can cause infectious diseases and the usual treatment is to give antibiotics or chemical compounds to diseases caused by these staphylococcus aureus bacteria. The purpose of this study was to determine the effect of ciplukan leaf filtrate on the growth of staphylococcus aureus bacteria. This research method was true-experimental research and the sample used in this study was ciplukan leaf filtarat (Physalisangulatalinn) taken from fresh ciplukan leaves. The results of the data were obtained by conducting a statistical test, namely the kruskalwalis test. Based on the results of research conducted at a concentration of $100 \%$ the inhibition zone diameter formed with an average of 20,333 $\mathrm{mm}$, and at concentrations of $75 \%, 50 \%$ and $25 \%$ the diameter of the inhibition zone was not formed.
\end{abstract}

\begin{abstract}
ABSTRAK
Bakteri staphylococcus aureus merupakan bakteri berbentuk cocus dan bersifat gram positif, bakter iini dapat menyebabkan penyakit infeksi dan pengobatan yang biasadilakukan adalah dengan memberikan obat antibiotic atau senyawa kimia terhadap penyakit yang ditimbulkan oleh bakteri staphylococcus aureus ini. Tujuan dari penelitian ini adalah untuk mengetahui pengaruh filtrate daun ciplukan terhadap pertumbuhan bakteri staphylococcus aureus. Metode Penelitian ini merupakan penelitian true-experimental dan sampel yang digunakan pada penelitian ini adalah filtarat daun ciplukan (Physalisangulatalinn) yang diambil dari daun ciplukan yang masih segar. Data hasil diperoleh dengan melakukan ujistatistik yaitu uji kruskalwalis.Berdasarkan hasil penelitian yang dilakukan pada konsentrasi $100 \%$ terbentuk diameter zona hambat dengan rata-rata $20.333 \mathrm{~mm}$, dan pada konsentrasi $75 \%$, 50\% dan $25 \%$ tidak terbentuk adanya diameter zona hambat.
\end{abstract}

Kata Kunci : Staphylococcus aureus; Diameter zona; Ciplukan.

\section{Pendahuluan}

Penyakit infeksi masih merupakan penyakit yang paling banyak diderita oleh penduduk di negara berkembang, termasuk Indonesia. Penyakit infeksi yang menyebabkan infeksi bagi hospes (manusia) dan terdapat dalam lingkungan hidup hospes, termasuk di tanah, air, udara, makanan, hewan dan lain-lain (Radjil M. 2011).

Insiden infeksi Staphppylococcus aureus terus meningkat di berbagai belahan dunia. Prevalensi infeksi Staphylococcus aureus mencapai $70 \%$ di Asia, sementara di Indonesia pada tahun 2006 prevalensinya 
berada pada angka 23,5\%. Infeksi luka operasi yang disebabkan bakteri Staphylococcus aureus di Indonesia dapat terjadi salah satunya di ruang perawatan bedah seperti infeksi nosokomial (Mahmudah, 2013).

Pengobatan terhadap penyakit yang disebabkan oleh bakteri Staphylococcus aureus dapat dilakukan dengan pemberian obat-obat kimia atau antibiotik. Antibiotik merupakan segolongan senyawa, baik alami maupun sintetik yang mempunyai efek menekan atau menghentikan suatu peroses biokimia didalam suatu oragnisme, khususnya dalam peroses infeksi oleh bakteri. Pencegahan Staphylococcus aureus yang paling baik saat ini adalah pemberian antibiotik. Penggunaan antibiotik sebagai obat untuk menanggulangi penyakit infeksi harus rasional, tepat dan aman. Penggunaan antibiotik yang tidak rasional akan menimbulkan dampak negatif, seperti meningkatnya efek samping obat, terjadi kekebalan kuman terhadap beberapa antibiotik, dan bahkan kematian, sehingga perlu dicari alternatif pengobatan yang memiliki efek samping yang relatif rendah dan biaya murah.Pengobatan infeksi Staphylococcusaureus biasanya menggunakan antibiotik turunan penisilin seperti metisilin dan oksasilin. Namun sebagian besar strain Staphylococcus aureus ditemukan telah resisten terhadap antibiotik penisilin sehingga antibiotik turunan penisilin sudah jarang digunakan seperti vankomisin dan teikoplanin (Lowy, 2003).

Tanaman ciplukan (Physalis angulata L.) adalah tanaman herbanual (tahunan) dengan tinggi 0,1 - 1 meter, habitat penyebaran dan budidaya ciplukan adalah tumbuhan asli Amerika yang kini telah tersebar secara luas di daerah tropis di dunia. Ciplukan (Physalis angulata L.) biasa tumbuh di daerah dengan ketinggian antara 1-1550 meter diatas permukaan laut. Pemanfaatan ciplukan dimasyarakat biasa digunakan sebagai obat cacing dan demam. Daunnya digunakan untuk penyembuhan patah tulang, busung air, bisul, borok, penguat jantung, keseleo, nyeri perut, dan kencing nanah. Buah ciplukan sendiri sering dimakan untuk mengobati epilepsy, tidak dapat kencing dan penyakit lainnya juga. Daun ciplukan biasa juga digunakan untuk pengobatan bisul karena memiliki beberapa senyawa aktif antibakteri sehingga digunakan sebagai obat bisul atau borok yang disebabkan oleh bakteri Staphylococcus aureus.

Adapun senyawa senyawa aktif yang terkandung dalam ciplukan antara lain saponin, flavonoid, polifenol, dan fisalin. Sejak lama, ciplukan sebenarnya telah diteliti akar dan batangnya oleh para ahli dari berbagai negara, dari penelitian yang telah dilakukan didapatkan informasi bahwa ciplukan memiliki aktivitas sebagai antihiperglikemi, antibakteri, antivirus, imunostimulan dan imunosupresan (imunomodulator), antiinflamasi, antioksidan dan antitoksik (Baedowi 1998).Dari uraian tersebut, maka penulis tertarik untuk melakukan penelitian untuk mengetahui pengaruh filtrate daun ciplukan (Physalis Angulata Linn) dalam menghambat pertumbuhan bakteri Staphylococcus aureus.

\section{Metode Penelitian}

Penelitian ini merupakan penelitian true-experimental karena dilakukan kontrol terhadap variabel yang bertujuan untuk mengetahui suatu gejala atau pengaruh yang timbul sebagai akibat dari adanya perlakuan tertentu (Notoadmodjo,2005).

\section{Hasil Penelitian}

Berdasarkan hasil penelitian pengaruh pemberian filtrat daun ciplukan (Physalis angulata linn) dalam media Muller Hinton Agar (MHA) terhadap pertumbuhan bakteri Staphylococcus aureus metode kirby bauer yang dilakukan di Laboratorium Analis Poltekkes Kemenkes Mataram, pada setiap perlakuan diperoleh hasil berupa diameter zona hambat yang terlihat pada tabel di bawah ini. 
Tabel 1. Diameter zona hambat dari filtrat daun ciplukan (Physalis angulata linn) terhadap pertumbuhan bakteri Staphylococcus aureus.

\begin{tabular}{|c|c|c|c|c|c|c|c|c|}
\hline $\begin{array}{l}\text { Perlakuan } \\
\text { (T) }\end{array}$ & \multicolumn{6}{|c|}{$\begin{array}{l}\text { Diameter zona hambat } \\
(\mathrm{mm})\end{array}$} & $\begin{array}{l}\text { Total hasil } \\
\text { perlakuan }\end{array}$ & $\begin{array}{l}\text { Rata-rata } \\
\text { hasil perlakuan }\end{array}$ \\
\hline \multirow[t]{2}{*}{$\mathrm{T} 1$} & $21 \mathrm{~mm}$ & $20 \mathrm{~mm}$ & $\begin{array}{c}21 \\
\mathrm{~mm}\end{array}$ & $9 \mathrm{~mm}$ & $0 \mathrm{~mm}$ & $1 \mathrm{~mm}$ & $122 \mathrm{~mm}$ & $20,333 \mathrm{~mm}$ \\
\hline & $0 \mathrm{~mm}$ & $0 \mathrm{~mm}$ & $0 \mathrm{~mm}$ & $0 \mathrm{~mm}$ & $0 \mathrm{~mm}$ & $0 \mathrm{~mm}$ & $0 \mathrm{~mm}$ & $0 \mathrm{~mm}$ \\
\hline $\mathrm{T} 2$ & $0 \mathrm{~mm}$ & $0 \mathrm{~mm}$ & $0 \mathrm{~mm}$ & $0 \mathrm{~mm}$ & $0 \mathrm{~mm}$ & $0 \mathrm{~mm}$ & $0 \mathrm{~mm}$ & $0 \mathrm{~mm}$ \\
\hline \multirow{2}{*}{$\begin{array}{l}\mathrm{T} 3 \\
\mathrm{~T} 4 \\
\mathrm{TC}(+)\end{array}$} & $0 \mathrm{~mm}$ & $0 \mathrm{~mm}$ & $0 \mathrm{~mm}$ & $0 \mathrm{~mm}$ & $0 \mathrm{~mm}$ & $0 \mathrm{~mm}$ & $0 \mathrm{~mm}$ & $0 \mathrm{~mm}$ \\
\hline & $30 \mathrm{~mm}$ & & & & & & $30 \mathrm{~mm}$ & $30 \mathrm{~mm}$ \\
\hline \multicolumn{7}{|c|}{ GT (Grand Total) } & $152 \mathrm{~mm}$ & $53,333 \mathrm{~mm}$ \\
\hline \multicolumn{7}{|c|}{ GT (Grand mean) } & $30,4 \mathrm{~mm}$ & $10,6 \mathrm{~mm}$ \\
\hline
\end{tabular}

Keterangan :

1,2,3,4,5,6 : Replikasi / Pengulangan

T1 : Pemberian filtrat daun ciplukan dengan konsentrasi $100 \%$.

T2 : Pemberian filtrat daun ciplukan dengan konsentrasi $75 \%$.

T3 : Pemberian filtrat daun ciplukan dengan konsentrasi $50 \%$.

T4 : Pemberian filtrat daun ciplukan dengan konsentrasi $25 \%$.

: Pemberian control ciprofloxacin.

Tabel 1. rata-rata diameter zona hambat dari masing-masing replikasi adalah : konsentrasi 100\% didapatkan diameter zona hambat, sedangkan pada konsentrasi 75\%, 50\% dan $25 \%$ tidak didapatkan diameter zona hambat, oleh karena itu daun tumbuhan ciplukan memiliki potensi dalam menghambat pertumbuhan bakteri Staphylococcus aureus dan data yang diperoleh layak untuk di uji statistik.

Hasil uji statistik terhadap pemberian filtrat daun ciplukan (Physalis angulata linn) pada konsentrasi yang bervariasi terhadap diameter zona hambat pertumbuhan bakteri Staphylococcus aureus menggunakan uji statistik Kruskal-Wallis yaitu uji non parametrik sebagai pengganti uji One Way Anova karena didapatkan hasil yang tidak berdistribusi normal. Hasil uji statistik untuk tes normalitas terdapat pada tabel 4.2 terlihat seperti tabel dibawah ini:

Tabel 2. Uji statistik Normalitas tes.

Test of Normality

\begin{tabular}{|c|c|c|c|c|}
\hline \multirow{2}{*}{ Daun ciplukan } & \multicolumn{2}{|c|}{$\begin{array}{c}\text { Solmogrov- } \\
\text { Smirnov }\end{array}$} & \multicolumn{3}{|c|}{ Shapiro-Wilk } \\
\cline { 2 - 5 } & \multicolumn{1}{c|}{ Sig } & Statistic & Df & Sig \\
\hline $\begin{array}{c}\text { Zona hambat }(\mathrm{mm}) \text { ciplukan } \\
100 \%\end{array}$ & $0.177 \quad$ & 0.822 & 6 & 0.091 \\
\hline
\end{tabular}

Pada tabel diatas terlihat bahwa pada konsentrasi $100 \%$ hasil dari tes normalitas dengan enam kali perlakuan diperoleh hasil pengaruh pemberian filtrat daun ciplukan (Physalis angulata linn) terhadap aktivitas pertumbuhan bakteri Staphylococcus aureus secara signifikan. 
Tabel 3.Hasil uji statistik descriptive (diameter zona hambat (mm)).

\begin{tabular}{|c|c|c|}
\hline Varietal & Rata-rata & $\mathrm{P}$ \\
\hline $\begin{array}{ll} & \text { Ciplukan } \\
100 \% & \end{array}$ & $\begin{array}{lll} & 20.333 \quad \pm \\
0,816 & & \end{array}$ & 0.333 \\
\hline Ciplukan $75 \%$ & $0.000 \pm 0.000$ & 0.000 \\
\hline Ciplukan 50\% & $0.000 \pm 0.000$ & 0.000 \\
\hline Ciplukan 25\% & $0.000 \pm 0.000$ & 0.000 \\
\hline Total & & 0.333 \\
\hline
\end{tabular}

Keterangan :

$\operatorname{sig}: \mathrm{P} \leq 0.00$

Varietal : Jumlah konsentrasi daun ciplukan

Rata-rata : nilai pada kolom rata-rata didapatkan dari Mean dengan standar deviation.

Dari penelitian yang telah dilakukan, data penelitian filtrat daun ciplukan tidak berdistribusi normal, sehingga digunakan uji Kruskal Wallis

Test Statistics $^{\text {a,b }}$

\begin{tabular}{|l|r|}
\hline & \\
\hline Chi-Square & Zona Hambat (mm) \\
\hline Df & \\
Asymp. Sig. & \\
\hline
\end{tabular}

a. Kruskal Wallis Test

b. Grouping Variable: Daun Ciplukan

\section{Pembahasan}

Staphylococcus aureus merupakan bakteri yang mudah tumbuh pada perbenihan bakteri dalam keadan aerob atau anaerob. Tumbuh paling cepat pada suhu $37^{\circ} \mathrm{C}$, tetapi membentuk pigmen paling baik pada suhu kamar (20-25 C). Media yang biasa digunakan untuk pertumbuhan bakteri Staphylococcus aureus adalah Manitol Salt Agar (MSA) karena Staphylococcus aureus memiliki kemampuan untuk memfermentasikan manitol menjadi asam, hal ini dapat dibuktikan bila Staphylocccus aureus dibiakkan dalam agar Manitol, dimana terjadi perubahan $\mathrm{pH}$ dan juga perubahan warna dari merah menjadi kuning. Pada penelitian ini dilakukan uji sensitivitas pada bakteri Staphylococcus aureus dengan sampel daun ciplukan (Physais angulata linn) dimana media yang digunakan pada uji ini adalah media Muller Hinton Agar (MHA) yang digunakan untuk uji sensitivitas,

Uji sensitivitas merupakan suatu pemeriksaan mikrobiologi untuk mengetahui kepekaan bakteri terhadap suatu antibiotik. Prinsip umum uji sensitivitas yaitu mengukur kemampuan zat antibiotik untuk mengukur diameter zona hambatnya (Vandepite dkk, 2010). Pada penelitian ini menggunakan bakteri Staphylococcus aureus dan antibiotik Ciprolaxacin sebagai kontrol positif dan metode yang digunakan pada penelitian ini yaitu metode sumuran Kirby bauer.

Penelitian ini bertujuan untuk mengetahui daya hambat dari filtrat daun ciplukan (Physalis anngulata linn) terhadap pertumbuhan bakteri staphylococcus aureus menggunakan metode difusi sumuran kirby bauer dengan membuat lubang pada agar media padat (muller hinton agar) yang telah diinokulasi dengan bakteri staphylococcus aureus kemudian di tuang filtrat daun ciplukan kedalam sumuran sebanyak $50 \mu 1$ tiap tiap sumuran, dimana pada konsentrasi $100 \%$ digunakan filtrat murni daun ciplukan tanpa tambahan aquades steril, sedangkan untuk konsentrasi 75\%,50\% dan 25\% dilakukan pengenceran dengan aquadest steril, pada penelitian ini control positifnya menggunakan antibiotik ciprofloxacin dan $\mathrm{Pz}$ steril, untuk control negative digunakan aquadest steril. Berdasarkan hasil penelitian tersebut terlihat bahwa control negative tidak 
membentuk zona hambat sedangkan pada control positif terbentuk zona hambat dengan diameter $30 \mathrm{~mm}$. Berdasarkan hasil penelitian yang telah dilakukan menggunakan filtrat daun ciplukan (Physalis angulata linn) pada konsentrasi $100 \%$ terbentuk zona hambat dengan diameter $21 \mathrm{~mm}$ pada replikasi pertama, $20 \mathrm{~mm}$ pada replikasi ke dua, $21 \mathrm{~mm}$ pada replikasi ke tiga, $19 \mathrm{~mm}$ pada replikasi ke empat, $20 \mathrm{~mm}$ pada replikasi ke lima dan $21 \mathrm{~mm}$ pada replikasi ke enam, total rata-rata diameter zona hambat dari enam replikasi adalah 20,333 mm. Terbentuknya diameter zona hambat ini dipengaruhi oleh senyawa aktif yang terdapat pada daun ciplukan (Physalis angulata linn) antara lain :

Flavonoid yaitu suatu zat aktif yang mampu menyebabkan terjadinya kerusakan permeabilitas dinding sel bakteri, mikrosom dan lisosom. Flavonoid juga mampu melepaskan energi transduksi terhadap membran sitoplasma bakteri dan menghambat motilitas bakteri (Quddus, 2012).

Alkaloid merupakan zat aktif yang juga memiliki kemampuan sebagai antibakteri. Mekanisme yang digunakan alkaloid adalah dengan cara mengganggu komponen penyusun peptoglikan pada sel bakteri sehingga lapisan dinding sel tidak terbentuk secara utuh dan menyebabkan kematian sel tersebut (Juliantina dkk, 2009) Polifenol mempunyai mekanisme kerja sebagai inhibitor enzim oleh senyawa yang teroksidasi. Fenol juga mendenaturasikan protein dan membran sel bakteri. Ketidakstabilan pada dinding sel dan membrane sitoplasma bakteri menyebabkan fungsi pengendalian susunan protein dari sel bakteri menjadi terganggu (Noorhamdani dkk., 2014).

Ciplukan (Physalis angulata linn) sendiri memiliki aktivitas sebagai antibakteri, antivirus, imunostimulan, antiinfalamsi, antioksidan, antitoksik dan imunosupresan dan mempunyai senyawa aktif seperti alkaloid, flavonoid dan polienol dimana senyawa aktif ini yang berfungsi sebagai antibakteri (Baedowi 1998). Dimama senyawa-senyawa aktif ini yang dapat mengganggu pertumbuhan dari bakteri tersebut. Akan tetapi pada konsentrasi yang berbeda yaitu konsentrasi 75\%, 50\% dan 25\% tidak terbentuk zona hambat dalam pembacaan 1 x 24 jam hal ini bisa dipengaruhi oleh pengenceran konsentrasi dan dapat juga dipengaruhi oleh cara kerja yang kurang baik. Akan tetapi pada konsentrasi $75 \%$ dengan diamkannya selama 2 x 24 jam terbentuk diameter zona hambat pada replikasi pertama diameternya $17 \mathrm{~mm}$, pada replikasi kedua diameternya $18 \mathrm{~mm}$, replikasi ketiga $17 \mathrm{~mm}$, replikasi keempat $17 \mathrm{~mm}$, pada replikasi kelima $17 \mathrm{~mm}$ dan pada replikasi keenam sepanjang $19 \mathrm{~mm}$, namun terbentuknya diameter zona hambat ini tidak dimasukkan kedalam uji statistik karena diameternya terbentuk pada inkubasi 2 × 24 jam. Pada konsentrasi 50\% tidak didapatkan diameter zona hambat dan pada konsentrasi25\% tidak membentuk diameter zona hambat sama sekali walaupun sudah di dimakan selama tiga hari hal ini bisa dipengaruhi oleh pengenceran sehingga dapat mengurangi kerja efektif dari zat aktif yang terkandung oleh daun ciplukan (Physalis anguata linn) sendiri.

Pada penelitian ini untuk mengetahui signifikan data hasil penelitian digunakan uji statistic Kruskal-wallis yaitu uji non parametric sebagai pengganti uji One way anova karena didapatkan hasil yang tidak berdistribusi normal. Pada penelitian ini didapatkan diameter zona hambat dengan rata-rata 20,333 mm. Berdasarkan diameter zona hambat menurut mukkherejee (1988) yang menyatakan diameter zona hambatan yang dibentuk oleh bakteri dengan menggunakan obat-obatan tradisional sensitive (+) apabila zona hambatan lebih dari $12 \mathrm{~mm}$, dikatakan intermediet $( \pm)$ apabila diameter zona hambat antara 4-12 mm, dan dikatakan resisten (-) apabila diameter zona hambatan kurang dari $4 \mathrm{~mm}$. Dari penelitian yang telah dilakukan rata-rata hasil yang didapatkan oleh daun ciplukan dalam menghambat pertumbuhan bakteri Staphylococcus aureus 20. $333 \mathrm{~mm}$.

\section{Kesimpulan}

Perlakuan dengan konsentrasi $100 \%$ terbentuk diameter zona hambat dengan rata-rata $20.333 \mathrm{~mm}$, dan pada konsentrasi $75 \%, 50 \%$ dan $25 \%$ tidak terbentuk adanya diameter zona hambat.

\section{Referensi}

Bergey’s, 1994. Manual Of Determinative Bacteriology. Manual Of Determinative Bacteriology.

F. Rahardi, 1996. Membuat kebun tanaman obat, Jakarta: Puspa Swara.

Jawetz, E., Melnick, J.L. \& Adelberg, E.A., 1996. Mikrobiologi Kedokteran 20th ed., Jakarta: EGC. 
Juliantina, F.R., Citra, D.A., Nirwani, B., Nurmasitoh, T., dan Bowo, E.T.2009. Manfaat sirih merah (Piper Crocatum) sebagai agen anti bacterial terhadapbakteri gram positif dan gram negative. Jurnal Kedokteran dan kesehatan Indonesia.1(1):12-20.

Kemas Ali Hanafiah, 2005. Dasar-Dasar Statistika, Jakarta: Rajawali Pers.

Maksum Radji, 2011. "Buku Ajar Mikrobiologi : Panduan Mahasiswa Farmasi \& Kedokteran". Jakarta : EGC.

Noorhamdani, AS., Rio, Julia,. Gracia, H. (2014). UjiEfektivitas Ekstrak Etanol Daun Ciplukan (Physalis angulata L.) Sebagai Antimikroba Terhadap Acinetobacter baumannii Secara in Vitro[Jurnal]-[strata satu]: Majalah Gracia Harahap. Jurnal Penelitian Fakultas Kedokteran Universitas Brawijaya. Diakes 28 Maret 2014.

Soekidjo Notoatmodjo, 2005. Metodologi Penelitian Kesehatan, Jakarta: Rineka Cipta.

Soemarno, 2000. Isolasi dan Identifikasi Bakteri Klinik. AAK. Yogyakarta

Silva MT, Simas SM, Batista TG, Cardarelli P, Tomassini TC. (2005). "Studies on antimicrobial activity in vitro of physalis angulataL. (solanacea) fraction and physalin Bbringing out the importance of assay determination. Mem.inst.Oswaldo Cruz 100 (7): 779-82

Todar, S., 2008. Staphylococcus aureus yang Dilihat dari Mikroskop Elektron.

Osho, T Adetunji, S O Fayemi, and DO Moronkola. (2010). Antimicrobial Activity Of Essential Oils Of Physalis Angulata. L. Afr J Tradit Complement Altern Med. 7(4):303-306

Quddus, Rahadyan Wijaya.(2012). Efektivitas Daya Antibakteri Ekstrak Sarang Lebah Madu (Propolis) Terhadap Bakteri Staphylococcus Aures. KTI Strata satu. Fakultas Kedokteran dan Ilmu Kesehatan Universitas Muhammadiyah Yogyakarta.

Mukherjee KL. 1988. Medical Laboratory Technology Vol II. Tata MC Graw : New Delhi 